\title{
Development of Kenaf Biochar in Engineering and Agricultural Applications
}

\author{
M. M. Harussani ${ }^{1} \cdot$ S. M. Sapuan ${ }^{1,2}$
}

Received: 16 August 2021 / Accepted: 27 October 2021 / Published online: 10 November 2021

(c) The Tunisian Chemical Society and Springer Nature Switzerland AG 2021

\begin{abstract}
The aim of this review is to investigate the recent development of kenaf derived biochar and its composites in various engineering and agricultural applications including nanostructure catalysts and polymer composites as kenaf biochar and activated carbon are mainly used as material adsorbents and soil amendments. A systematic review on the effect of process parameters of thermal decomposition, pyrolysis towards the production of desired biochar, therefore, is in crucial needs. Based on existing literature, the properties and production of kenaf biomass and resultant biochar are discussed in this paper. This analysis focuses on the unique characteristics of kenaf crops and the resulting biochar, which has a surprisingly large surface area and increased pore volume, to explain their prospective applications, whether in environmental utilization or engineering applications. Range of optimum surface areas for kenaf biochar are around $800-1000 \mathrm{~m}^{2} / \mathrm{g}$ where they show high adsorption properties. Whereas, the pore volume of activated carbon usually exceeds $1 \mathrm{~cm}^{3} / \mathrm{g}$. Recent developments in engineered kenaf biochar technology and its future directions for research and development are also discussed.
\end{abstract}

Keywords Kenaf biochar $\cdot$ Agricultural waste $\cdot$ Pyrolysis $\cdot$ Composites $\cdot$ Kenaf crops

\section{Introduction}

Biomass supply systems inherit the expertise of established agriculture and forestry sectors, even though the widespread use of agricultural products and logging wastes for the generation of bioenergy is emerging. Biomass feedstocks are regarded as a clean energy sources due to their efficient and long-term use may significantly reduce the environmental effect of fossil fuels $[1,2]$. Thus, biomass feedstocks or also called as renewable carbon source are mainly originated from plants and plant-based materials which were left behind, they are abundant, renewable and the best possible alternatives of sustainable supply for bio fuels, bio products and bio energy generation. According to Faaij [3], biomass

S. M. Sapuan

sapuan@upm.edu.my

1 Advanced Engineering Materials and Composites Research Centre (AEMC), Department of Mechanical and Manufacturing Engineering, Universiti Putra Malaysia, 43400 UPM Serdang, Selangor, Malaysia

2 Laboratory of Biocomposite Technology, Institute of Tropical Forestry and Forest Products (INTROP), Universiti Putra Malaysia, 43400 UPM Serdang, Selangor, Malaysia feedstocks that can be used for energy are diverse: (1) primary residue, produced during production of food crops and forest products which mainly referred to agricultural or forestry residues; (2) secondary residues, yielded during stage of processing biomass into products at processing facilities like saw-mill; and (3) tertiary residues which related to the biomass derived wastes, varying from the organic components of municipal solid wastes, sludge and waste wood.

Kenaf (Hibiscus cannabinus L.) is regarded as an industrial crop, and belongs to family Malvaceae and is grown commercially in various geographical regions including Central Africa, India, Bangladesh, Thailand and Malaysia $[4,5]$. Kenaf is the most significant cultivated plant for fibre production throughout the globe, second to cotton, and was widely used as medicinal herbs in ancient Africa. It has already been grown in Africa for 4000 years, and its components have been utilized by indigenous tribes for animal feed, food, handcraft production, and fuel $[6,7]$. The kenaf crop is gaining popularity as a high-yielding "nonfood crop" for fibre production, notably in the newspaper, pulp, and other paper-based industries. Its quick growth and higher yielding rate are associated to the facile pulp processing as well as easy-to-grow, in terms of progressive maturity in dry, shallow and sandy soils, and low-water content 
environments. Figure 1 shows the scenery in a kenaf field cultivated in one of the Far East countries. Recently, about $79 \%$ of total kenaf production belongs to India, China, and Africa, contributing to $46 \%$ (100,000 tonnes), $26 \%$ and $7 \%$ to the world kenaf production, respectively [8].

Kenaf is agricultural biomass/feedstock, utilized with the thermal decomposition to yield biochar, from several researchers, prior to exposure with acid chemical activating agent to produce low-price activated carbon [10]. Pyrolysis is the most widely used and successful method for producing biochar, carbonization of biomass [10]. In addition, one of the most significant avenues to better biofuels is thermochemical conversion utilizing the pyrolysis process. In the absence of oxygen, the thermal breakdown converted the biomass solid matrix into gaseous, liquid, and solid components. The primary feedstock compositions and experimental pyrolysis settings impact the features and compositions of these different by-products; which mainly dominated by the production of solid biochar [11, 12]. Biochar, a porous carbon comparable to activated carbon, offers numerous agronomic and environmental beneficial effects, including soil improvement, surface pollution adsorption, and inorganic and organic pollutant remediation in grounds [13].

Biochar, charcoal, and activated carbons are three carbon compounds with a lot of similarities in structure and processing mechanics $[14,15]$. In anaerobic environments, biochar propensity for lower temperatures, below $700{ }^{\circ} \mathrm{C}$, is particularly advantageous with respect to minimal maintenance relative to activated carbon manufacturing. Furthermore, because of its large surface area, comparable porosity, and functional groups, biochar has the same great promise as activated carbon to be used as an adsorbent in water treatment. Evaluating a biomass source's biochar potential is an environmentally interesting method since the material is readily available in huge quantities which is also readily decomposed [16]. The biochar generated was not further burned to generate energy; instead, it was used as a soil amendment, where it has been found to enhance water and nutrient storage, reduce bulk density, and enhance $\mathrm{pH}$ values [17] to be utilized for several applications.

\section{Agriculture Waste of Kenaf Fibre as Biomass for Biochar}

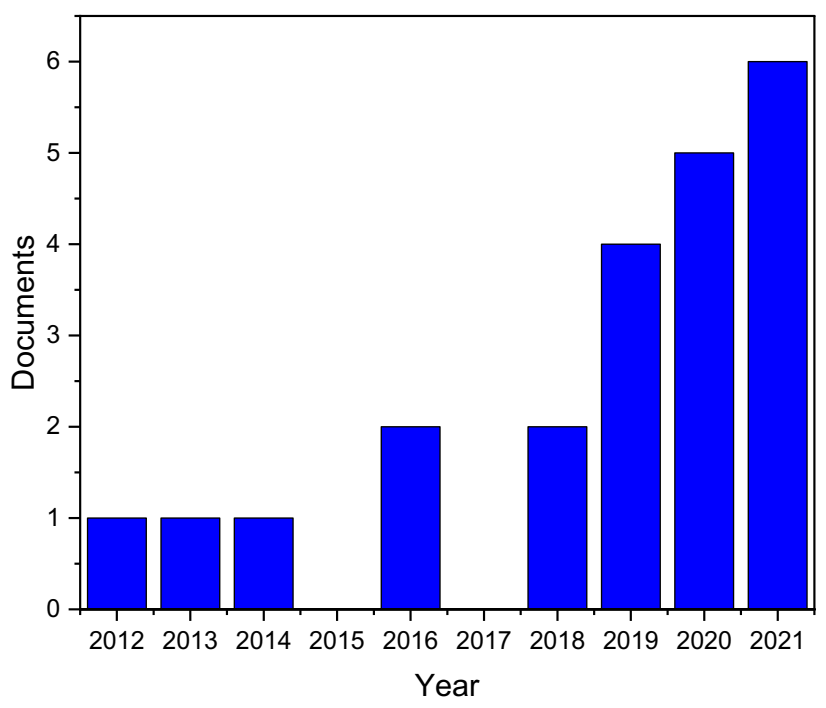

Fig. 2 Number of publications with topic of "kenaf biochar" from the year 2012 to 2021 (Source: Scopus, 9 October 2021). Many studies have examined the production of biochars from a wide variety of feedstocks into numerous applications including agricultural [18, 19], engineering [20,21], wastewater treatments [22], electrochemical uses and renewable energy generation [23], with both positive and negative results. However, from this Fig. 2, there are only 22 publications related to the keyword "kenaf biochar" were discovered in Scopus (9th October 2021) from the year 2012 to 2021. In addition, there are only 57 scholarly works related to "kenaf biochar" were recorded from Lens.org (data extracted from https://www.lens.org on 9th October 2021). According to Web of Science, there are at least only 18 papers found related to the keyword where none of them is review work. Thus, these findings indicate the novelty of this work regarding providing literature review towards research on kenaf biochar throughout the globe. As for the novelties of this work, this paper elaborates on the fundamentals of biochar and its pyrolysis design, chemical and physical characteristics of kenaf biochar, as well as the developments and applications of biochar, especially kenaf derived biochar, in various sectors; agriculture, renewable energy, water purifications and composites engineering

Fig. 1 Calm view of kenaf field in Far East countries [9]

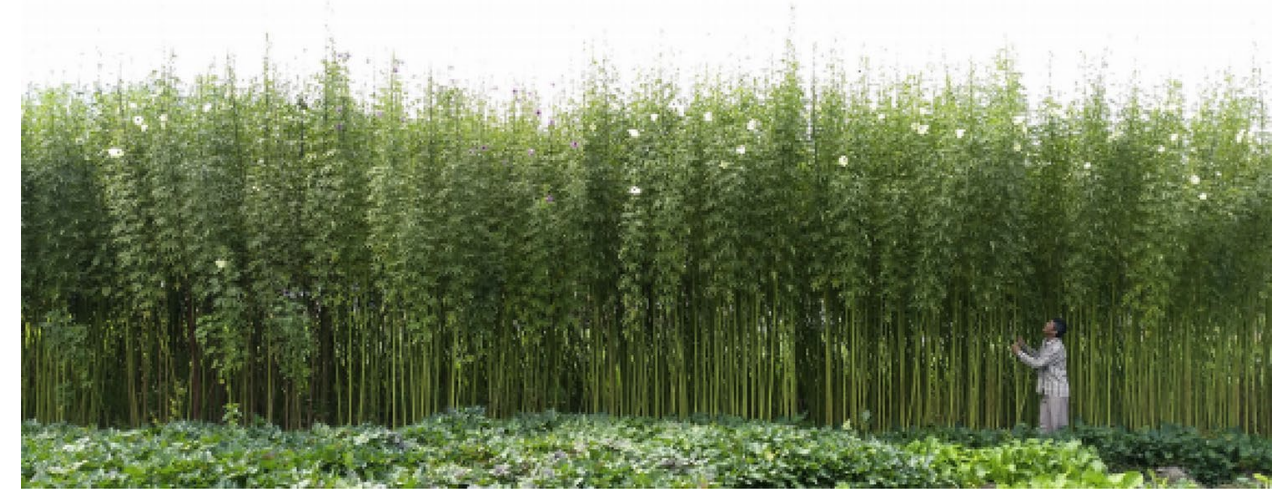


Kenaf (Hibiscus Cannabinus L.) has been grown for its stem-derived fibres, which are often used for rope, during the last decade, as shown in Fig. 3. After fibre extraction, the rest of the plant is either left in nature or burned for heating or cooking, which plainly pollutes the environment. Furthermore, kenaf is regarded to be one of the most promising plants, leads to improved agricultural practices, enhanced processing processes, and research on future development [24]. Kenaf is a tropical annual herbaceous plant that is used in agriculture. This fibrous, herbaceous plant ranks third in biomass output and exhibits rapid growth rate, which takes less than 6 months to reach a size to be considered as matured suitable for practical uses [25]. The use of kenaf fibre cellulose has both environmental and economic benefits; for instance, it can grow up to $3 \mathrm{~m}$ tall with a $3-5 \mathrm{~cm}$ base diameter in 3 months under such a broad range of climatic circumstances, making it ideal for natural fibre surfaces and composites [26, 27]. When compared to other plants as potential sources of biochar materials, the crop provides a low-cost and ecologically safe choice in terms of its high fibre and cellulose component. Furthermore, kenaf is readily generated and widely available, particularly in tropical areas; these important features make kenaf an excellent biochar material [16]. Long fibres make for roughly $30 \%$ of the overall plant volume, whereas short fibres account for the remaining $70 \%$ of the plant volume [10].

Kenaf is a multipurpose plant which could provide a variety of lucrative by-products for consumers and businesses. As a result, kenaf is widely utilized in pulp, paper, and cardboard manufacturing, as well as fibre reinforced composites, natural fuels, cellulose products, absorbent agents, and animal feed [30]. Kenaf has a low density, is very absorbent, is non-abrasive during processing, has excellent specific mechanical characteristics, and is biodegradable. Turning char by-product into carbon particles is one of the value-added benefits [2]. The carbon compounds might be employed in water and beverage purification systems, as well as in electrode manufacturing technologies as supercapacitor electrodes. The size distribution, surface area, pore diameters, and flexibility of biochar determine its quality. The mass ratio, milling hours, and sample post-treatment all play a role in producing high-quality biochars. These can be obtained by fine-tuning the process parameters throughout the manufacturing
Fig. 3 Kenaf plants as biomass feedstocks [28, 29]

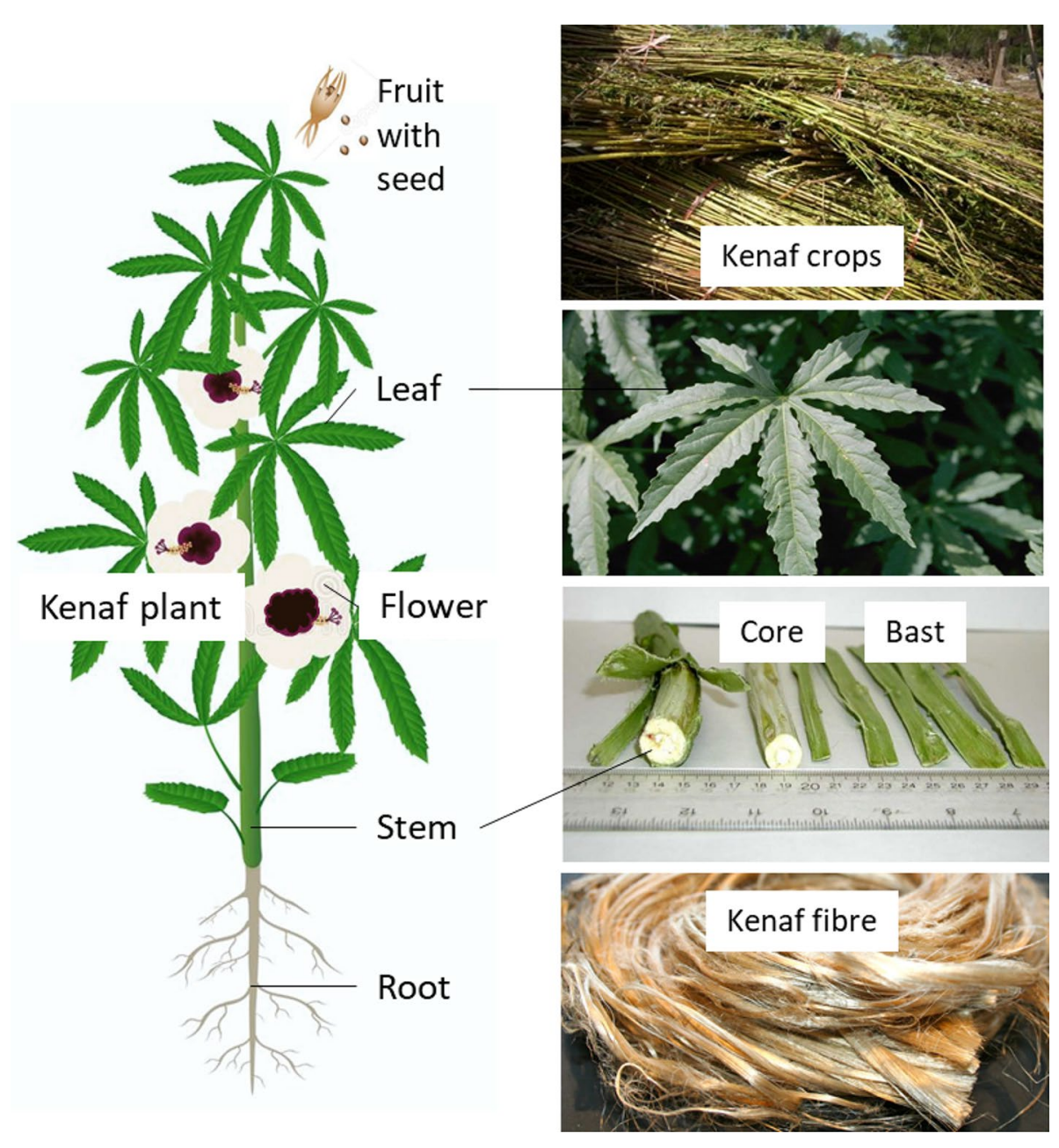


process [31]. Consequently, biochar generated from kenaf fibres, which originate from its stems and leaves, has been utilized in a wide range of applications, including wastewater treatment [32], biofuels generation including biogas, bioethanol, biodiesel, and biohydrogen [9], polymer composites [33, 34], and horticultural substrate synthesis [35].

\subsection{Proximate and Ultimate Analysis of Kenaf Fibre}

The dried kenaf stems are shown in Fig. 4. The ultimate and proximate analyses, as well as the inorganic concentration in the kenaf samples, are shown in Table 1. The results are within the range of typical agricultural and food processing residue compositions described in the literature $[24,36]$. The carbon content of raw kenaf is estimated to be around $47.32 \mathrm{wt} \%$, according to the elemental composition of ultimate analysis. In addition, the production of biochar due to slow pyrolysis suggesting a fixed carbon content of $15.80 \mathrm{wt} \%$. From the study, the heating value (HHV) and low heating value (LHV) of the kenaf fibre is $18.54 \mathrm{MJ} / \mathrm{kg}$ and $17.38 \mathrm{MJ} / \mathrm{kg}$, respectively, which is comparable to the HHV of other biomasses [23, 37].

The elemental composition study in Table 2 reveals that the major minerals found in the kenaf stems are $\mathrm{K}(20.59 \mathrm{~g} / \mathrm{kg}), \mathrm{Ca}(8.16 \mathrm{~g} / \mathrm{kg}), \mathrm{P}(3.29 \mathrm{~g} / \mathrm{kg})$, and $\mathrm{Mg}$ $(1.75 \mathrm{~g} / \mathrm{kg})$. These components, in its char yielded via slow pyrolysis, are extremely beneficial to plant growth and development.

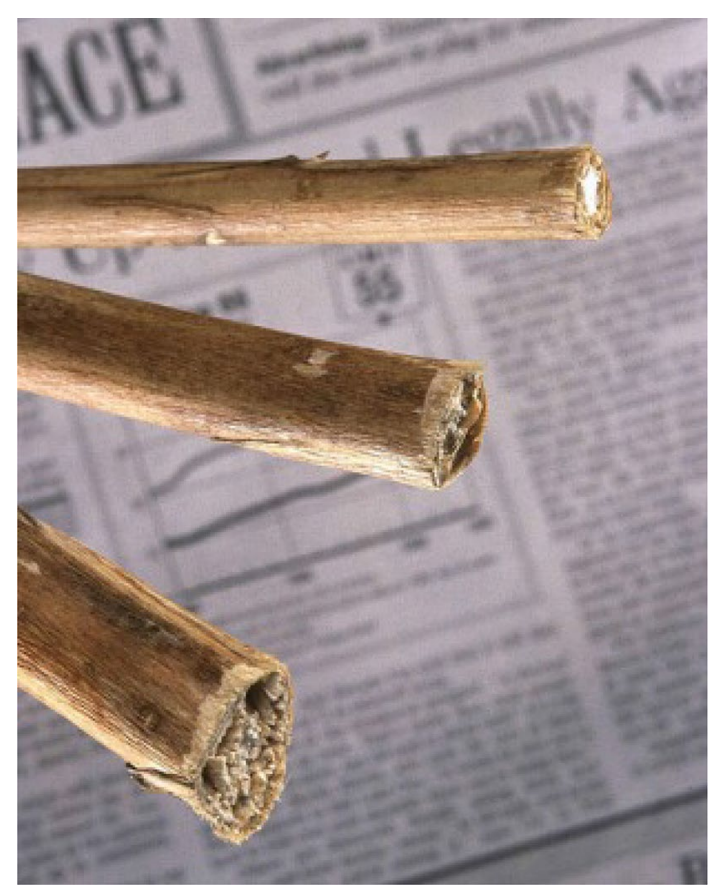

Fig. 4 Dried kenaf stems

Table 1 Proximate analysis (wt $\%$ ) of kenaf fibre

\begin{tabular}{ll}
\hline Moisture content & 4.4 \\
Volatile matter & 83.05 \\
Fixed carbon & 15.80 \\
Ash & 1.15 \\
LHV $(\mathrm{MJ} / \mathrm{kg})$ & 17.38 \\
$\mathrm{HHV}(\mathrm{MJ} / \mathrm{kg})$ & 18.54 \\
\hline
\end{tabular}

\subsection{Chemical Characteristics of Kenaf Fibre from Different Parts}

Chemical composition variations occur along the stalks/ branches of kenaf plant. From the bottom part of the stalks or branches to the top, the concentration of $\alpha$-cellulose, lignin, and ash declines. This was hypothesized as mature tissues acquire more metabolic products than younger tissues located at the top part [38]. Several studies [39-41], however, have shown that the bast and core differ significantly in morphologic structure as well as in chemical composition.

Chemically, the chemical components of kenaf bast and core were significantly distinct. Table 3 shows the chemical analytical results for the entire kenaf (including its core and bast), kenaf core and bast [24, 36]. Excluding the ash, the percentages of all the chemical components of kenaf (nonwood) are more or less identical to those of wood products, according to the findings of this study. When compared to wood products, kenaf had a higher ash content. This demonstrated that the non-wood fibres had a significant silica content, which was known to be a disadvantage in mechanical strength qualities for the end products [40, 42]. The ash content of whole kenaf, its core, and its bast fibers was $4 \%$, $1.9 \%$, and $5.4 \%$, respectively. Extractive was often wasted and was not utilized in manufacturing and production.

Table 2 Elemental and mineral composition of kenaf fibre

\begin{tabular}{cc}
\hline Elemental composition $(w t \%)$ \\
$\mathrm{C}$ & $47.32( \pm 0.8)$ \\
$\mathrm{H}$ & $5.20( \pm 0.3)$ \\
$\mathrm{N}$ & $0.38( \pm 0.03)$ \\
$\mathrm{S}$ & $<0.02$ \\
$\mathrm{O}$ & 47.1 \\
$\mathrm{Mineral}$ & composition $(\mathrm{g} / \mathrm{kg})$ \\
$\mathrm{Al}$ & 0.30 \\
$\mathrm{Ca}$ & 8.16 \\
$\mathrm{Fe}$ & 0.38 \\
$\mathrm{~K}$ & 20.59 \\
$\mathrm{Mg}$ & 1.75 \\
$\mathrm{Zn}$ & 0.12 \\
$\mathrm{Cl}$ & 0.23 \\
$\mathrm{P}$ & 3.29 \\
$\mathrm{Si}$ & 1.50 \\
\hline
\end{tabular}


Table 3 Chemical composition of different fractions of kenaf fibre [43]

\begin{tabular}{llllll}
\hline & \multicolumn{5}{l}{ Wood } \\
\cline { 2 - 6 } & Kenaf bast & Kenaf core & $\begin{array}{l}\text { Kenaf whole (core } \\
\text { and bast) }\end{array}$ & Softtwood & Hardwood \\
\hline Holocellulose (\%) & 86.8 & 87.8 & 87.7 & $60-80$ & $71-90$ \\
$\alpha$-Cellulose (\%) & 55.0 & 49.0 & 53.8 & $30-60$ & $31-64$ \\
Lignin (\%) & 14.7 & 19.2 & 21.2 & $21-37$ & $14-34$ \\
Extractive (\%) & 5.5 & 4.7 & 6.4 & $0.2-8.5$ & $0.1-7.7$ \\
Ash (\%) & 5.4 & 1.9 & 4.0 & $<1$ & $<1$ \\
\hline
\end{tabular}

According to Table 3, the percentage of chemical composition in kenaf fibres showed that kenaf core fibres were higher in holocellulose and lignin, whereas kenaf bast fibres were higher in $\alpha$-cellulose and ash content when compared to others [44]. The high $\alpha$-cellulose content of bast fibre is assumed to provide high strength in paper formation and other fibre end products. It was mentioned that the cellulose (bast fibre 52-59\%, core 44-46\%) and lignin (bast fibre 9.3-13.2\%, core $18.3-23.2 \%$ ) contents of the kenaf plant increased significantly during maturation [45]. Figure 5 shows the SEM images of kenaf core fibres and bast fibres.

Kenaf lignin was comprised of three major lignin units in varying ratios: $p$-hydroxyphenyl, guaiacyl, and syringyl. The total lignin content of the kenaf stalk (core and bast) was approximately $21.2 \%$, which was higher than the results acquired by Kuroda et al. [39]. Due to their reduced lignin composition, the core and bast samples comprised $19.2 \%$ and $14.7 \%$ lignin, respectively, which was slightly lower than that of softwood (21-37\%) and is favourable for pulping compared to wood. The analysis of plant material samples at different heights/lengths revealed that lignin and cellulose concentration vary with tissue maturity however do not vary considerably within each species. Paper strength is also affected by the lignin and cellulose content of raw plant materials; pulp mechanical strength, particularly tensile strength, is directly proportional to cellulose content, whereas lignin is an undesirable polymer that
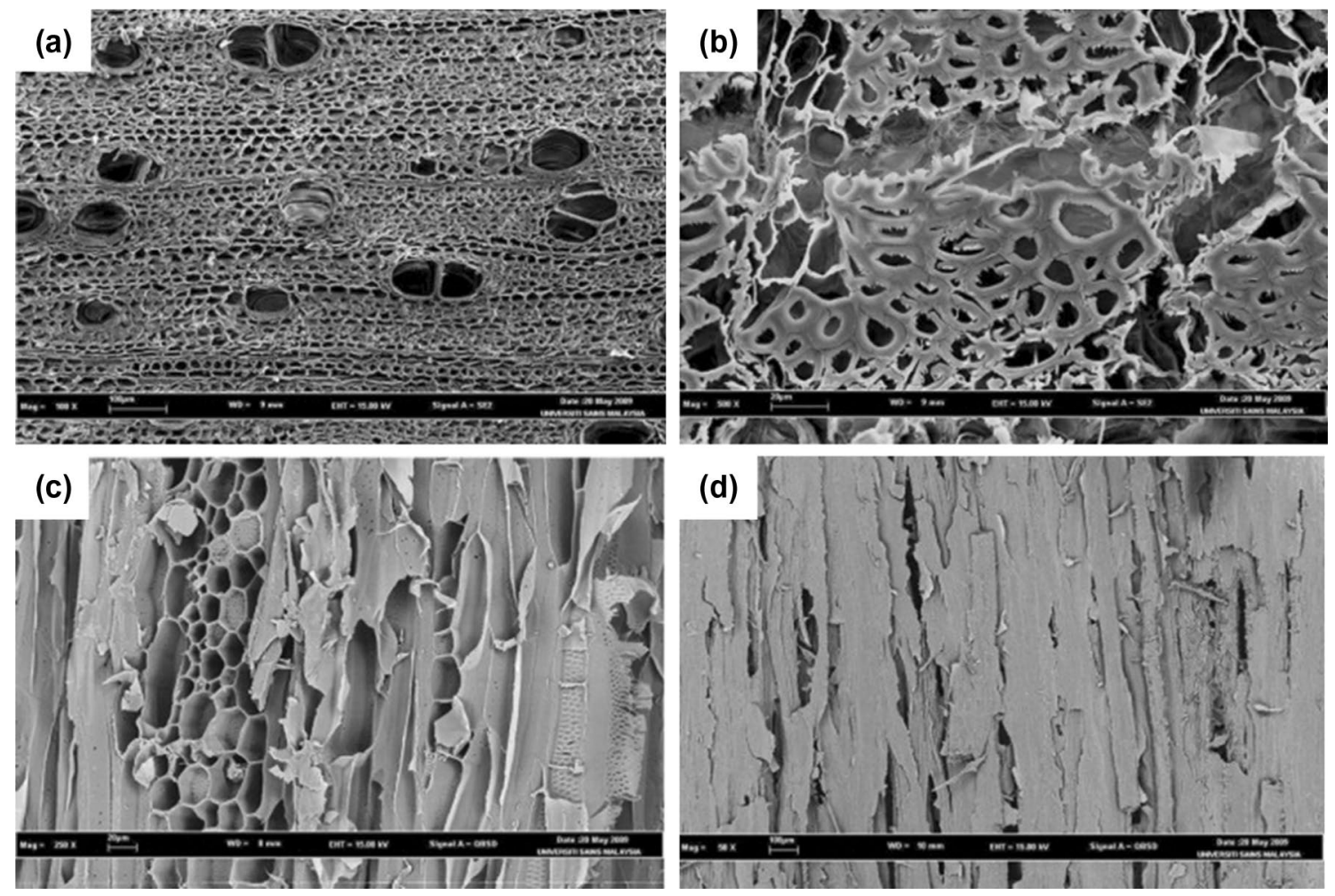

Fig. 5 Scanning electron micrograph of kenaf fibre at different parts: transverse section of a core fibres, and $\mathbf{b}$ bast fibres; longitudinal section of $\mathbf{c}$ core fibres, and $\mathbf{d}$ bast fibres 
requires a lot of energy and chemicals to remove during the pulping process [40].

\section{Manufacture of Kenaf Biochar and Its Characteristics}

\subsection{Pyrolysis Design for Kenaf Fibre Biochar}

Biochar is a solid residue generated through the thermal decomposition of biomass into fuel by-products [46], and it has traditionally been considered as a lower-value by-product compared to syngas and bio-oil, which are even more desirable. Kenaf biochar is produced by carbonizing kenaf stems at $1000{ }^{\circ} \mathrm{C}$ in an inert environment $[47,48]$. From another work, according to Yusof et al. [31], biochar is made from biomass compounds that are pyrolysed/gasified under controlled conditions in the absence of oxygen at temperatures ranging from 300 to $1000{ }^{\circ} \mathrm{C}$. Incomplete gasification produced charcoal, also known as bio-char or agri-char, which is a by-product of pyrolysis technology used in biofuel and ammonia manufacturing. These processes created a large amount of biochar, necessitating a greater use of it. It is also possible to assist agricultural operations become more sustainable, dependable, and tangibly create a healthier green environment, despite the fact that it may be turned from waste to wealth [31].

Based on previous works, Saeed et al. [50] proposed the value range of the pyrolysis temperature for kenaf from 300 to $600{ }^{\circ} \mathrm{C}$. The range was chosen based on prior research's recommendations $[31,32,51]$ which stated that the kenaf mass loss was attributed to three main stages: (1) drying and evaporation of light particles, happened at temperatures below $150{ }^{\circ} \mathrm{C}$, (2) volatilization of hemicellulose and cellulose, started degassing from 150 to $375^{\circ} \mathrm{C}$, and (3) decomposition of lignin, at temperatures above $400{ }^{\circ} \mathrm{C}$. As a result, the suggested pyrolysis temperature range was $300-600{ }^{\circ} \mathrm{C}$, which helped convert lignin into biochar while also keeping biochar stable. The pyrolysis temperature generally dominates the impact of residence time. As a result, determining the effect of residence time in biochar stability might be difficult at times [52]. The heating rate was set at $10{ }^{\circ} \mathrm{C} / \mathrm{min}$, which was deemed low though ideal for generating biochar from agricultural biomass [53] (Fig. 6). Moreover, a lower heating rate facilitated the development of aromatic structures in biochar and the preservation of structural complexity, whereas a high heating rate promoted the loss of structural complexity owing to local melting of cell structures, phase transitions, and swelling [54] (Table 4).

\subsection{Kenaf Biochar Characteristics}

When activated, microporous carbon with a large surface area generated in this way might be employed in pollution removal [58]. In anaerobic circumstances, biochars propensity for lower temperatures (below $700{ }^{\circ} \mathrm{C}$ ) is particularly advantageous in perspective of minimal maintenance contrasted to activated char manufacturing. On the other hand, the heating value of kenaf residues in the fluidized bed gasification method is thought to be inefficient for generating electricity [59], even if the generated gas could fulfil the demand for energy generation by gas engines.

Furthermore, several pyrolysis products produced from the entire kenaf were discovered [10, 16, 24, 31], mainly bio-oil and biochar, with the possible to be transformed into more valuable chemicals, and their distribution was found to be comparable to that of hardwood, which the primary products are syringol and guaiacol compounds. The phenol concentration of the kenaf core pyrolysate was greater than that of the kenaf cuticle, indicating that the kenaf core had
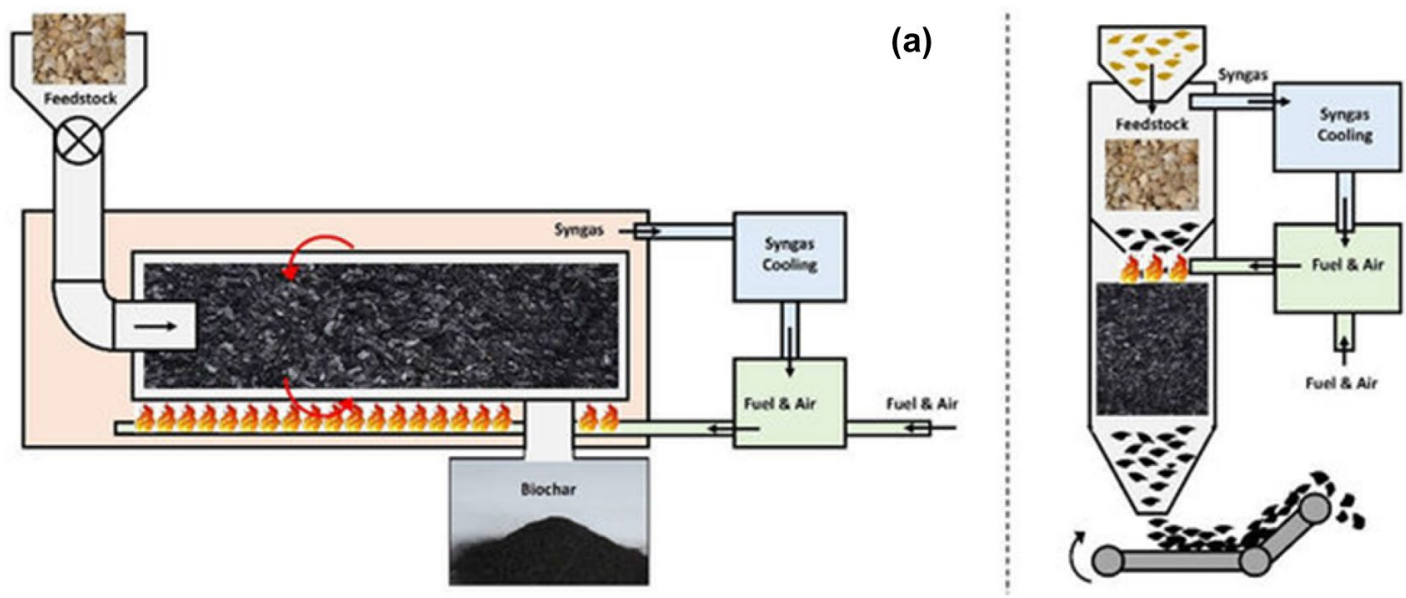

(b)

Fig. 6 Schematic illustrations of a horizontal pyrolysis reactor (such as rotary kiln reactor) and $\mathbf{b}$ vertical pyrolysis reactor (such as free-fall reactor) used to pyrolysed biomass feedstocks [23, 49] 
Table 4 Literature work on pyrolysis of kenaf to yield biochar with different pyrolysis parameters

\begin{tabular}{|c|c|c|c|c|c|c|c|}
\hline Biomass waste & $\begin{array}{l}\text { Tempera- } \\
\text { ture range } \\
\left({ }^{\circ} \mathrm{C}\right)\end{array}$ & $\begin{array}{l}\text { Resi- } \\
\text { dence } \\
\text { time (h) }\end{array}$ & $\begin{array}{l}\text { Heating } \\
\text { rate }\left({ }^{\circ} \mathrm{C} /\right. \\
\min )\end{array}$ & $\begin{array}{l}\text { Flowrate of } \\
\text { inert gases (L/ } \\
\text { min) }\end{array}$ & $\begin{array}{l}\text { Biochar } \\
\text { yields } \\
(\mathrm{wt} \%)\end{array}$ & Application & References \\
\hline Kenaf & $300-750$ & 1 & 20 & 0.5 & 24.6 & Triclosan adsorption of $77.4 \mathrm{mg} / \mathrm{g}$ & {$[55]$} \\
\hline Kenaf fibre & 550 & 3 & 10 & 100 & 28.6 & $\mathrm{Cd}^{2+}$ biochar adsorbent $23.48 \mathrm{mg} / \mathrm{g}$ & {$[50]$} \\
\hline Kenaf fibre & 1000 & 3 & 5 & - & - & $\begin{array}{l}\text { Oxidative degradation of bisphenol } \mathrm{A} \text { in } \\
\text { water }\end{array}$ & {$[56]$} \\
\hline Kenaf core & 400 & 1 & 7 & - & 35.44 & $\begin{array}{l}\text { Highly efficient removal of selected } \\
\text { endocrine-disrupting compounds }\end{array}$ & {$[16]$} \\
\hline Kenaf fibre waste & 500 & 1 & - & 100 & 20 & Adsorbents & {$[10]$} \\
\hline Kenaf stem & $400-600$ & 1 & 20 & 10 & 31 & $\begin{array}{l}\text { Pollutants removal or gas storage and soil } \\
\text { amendments }\end{array}$ & {$[24]$} \\
\hline Kenaf stem & 500 & 1 & 5 & 10 & 30 & Soil amendments & [57] \\
\hline
\end{tabular}

more lignin. Kenaf has a low overall bio-oil production when equalled to wood, yet a high yield when compared to other agricultural crops [60].

\subsubsection{Kenaf Biochar Chemical Characterization}

Biochar is one of the most important kenaf stems pyrolysis by-products. Biochar will be produced during the final pyrolysis of kenaf feedstocks as shown in Fig. 7. Several main pyrolytic parameters, including such process temperature, heating rate, feed rate, catalysts, and pressure, will influence the formation of biochar [2, 63]. According to previous studies, the biochar yields are decreases with increasing of the used pyrolysis temperature [64]. The char obtained by pyrolysis will be characterized via several analyses.

3.2.1.1 Ultimate and Proximate Analysis Table 5 lists the chemical properties of kenaf biochars as determined. The carbon, hydrogen, nitrogen, oxygen, sulphur and ash content of kenaf biochar were approximately between 40.0-90.0, $1.0-3.0,0.01-1.20,10.0-50.0,0.0-0.5$, and 10.0-40.0\%, respectively. Proximate analyses of the different biochars are summarized in Table 6. Comparison between the different pyrolysis temperatures shows higher amounts of volatiles matter at $400{ }^{\circ} \mathrm{C}$ which decrease with increasing of temperature from 34.5 to $19.9 \mathrm{wt} \%$ at $600{ }^{\circ} \mathrm{C}$. On the contrary, the weight loss associated with the fixed carbon increases with the increase of pyrolysis temperature from 60.2 to $73.2 \mathrm{wt} \%$. Similar trend is recorded for ashes. Such result can be attributed to the low inorganic contents which is vital due to their abilities to produce low ash and high fixed carbon contents [36].

\subsubsection{Mineral and Elemental Compositions Table 7} reveals that $\mathrm{Mg}$ and $\mathrm{K}$ are the most abundant mineral elements in the charcoal. Kenaf biochar contains non-negligible amounts of $\mathrm{Ca}, \mathrm{P}, \mathrm{Zn}$, and $\mathrm{Na}$. As a result of the decomposition/devolatilization of a portion of the kenaf, the biochars are rich in carbon and minerals. As a result, the use of kenaf char as an agricultural additive might be suggested.

3.2.1.3 Specific Surface Area Charcoals are non-specific or at least poorly specific adsorbents, exhibiting numerous macro-and transition pores of various diameters, and as a consequence of the large surface areas. Range of optimum surface areas for kenaf biochar are around $800-1000 \mathrm{~m}^{2} / \mathrm{g}$ where they show high adsorption properties [68]. Table 5 shows the findings of the BET surface area study and the
Fig. 7 a FESEM images of kenaf biochar pyrolyzed at $450{ }^{\circ} \mathrm{C}$ and $\mathbf{b}$ image of kenaf biochar yielded via slow pyrolysis [55]

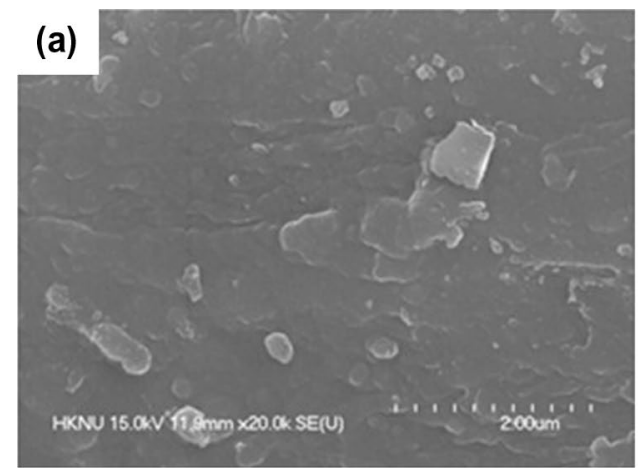

(b) 
Table 5 Chemical characteristics of kenaf and its biochar

\begin{tabular}{|c|c|c|c|c|c|c|c|c|c|c|c|}
\hline \multirow[t]{2}{*}{ Biochar } & \multirow{2}{*}{$\begin{array}{l}\text { Pyrolysis } \\
\text { temperature } \\
\left({ }^{\circ} \mathrm{C}\right)\end{array}$} & \multirow{2}{*}{$\begin{array}{l}\text { Specific } \\
\text { surface area } \\
\left(\mathrm{m}^{2} / \mathrm{g}\right)\end{array}$} & \multirow{2}{*}{$\begin{array}{l}\text { Pore } \\
\text { volume } \\
\left(\mathrm{cm}^{3} / \mathrm{g}\right)\end{array}$} & \multirow[t]{2}{*}{ Pore width $(\mathrm{nm})$} & \multicolumn{6}{|c|}{ Elemental composition (wt\%) } & \multirow[t]{2}{*}{ References } \\
\hline & & & & & $\mathrm{C}$ & $\mathrm{H}$ & $\mathrm{N}$ & $\mathrm{O}$ & $S$ & Ash & \\
\hline Raw kenaf core & 400 & 1.1381 & 0.0212 & 464.54 & 46.210 & 2.850 & 0.510 & - & 0.510 & - & {$[16]$} \\
\hline Bleached kenaf core & 400 & 4.8168 & 0.0001 & 38.79 & 49.650 & 2.110 & 0.013 & - & 0.480 & - & [16] \\
\hline Biochar & 550 & 117.70 & 0.0639 & 2.17 & 67.52 & 1.270 & 1.23 & 19.18 & - & 10.80 & {$[61]$} \\
\hline Magnetic biochar & 550 & 175.55 & 0.1024 & 2.33 & 58.32 & 1.120 & 1.06 & 25.75 & - & 13.75 & {$[61]$} \\
\hline Kenaf fibre biochar & 1000 & 289.50 & - & - & 50.50 & 1.878 & 0.268 & 8.47 & 0.025 & 38.86 & {$[62]$} \\
\hline $\mathrm{HCl}$ treated $\mathrm{KFC}$ & 1000 & 346.57 & 0.0040 & $\sim 3.00$ & 55.54 & 1.957 & 0.142 & 39.31 & 0 & 3.049 & {$[62]$} \\
\hline Kenaf & 500 & 261.20 & & & 97.70 & - & - & - & 0.075 & & [57] \\
\hline Kenaf biochar & 500 & 261.20 & 0.088 & 1.36 & 67.50 & & & & 1.5 & 6.6 & {$[24]$} \\
\hline Kenaf fibre biochar & 500 & 11.4 & 0.017 & 5.92 & 46.70 & 2.31 & 1.2 & 56 & 0.113 & 22.7 & {$[10]$} \\
\hline Kenaf biochar & 450 & 4.6 & 0.0224 & 19.26 & 54.10 & 2.2 & 0.7 & 12.1 & 0.6 & & [55] \\
\hline
\end{tabular}

Table 6 Proximate analyses of the produced biochars (\%)

\begin{tabular}{llllll}
\hline Biochar & $\begin{array}{l}\text { Mois- } \\
\text { ture } \\
\text { content }\end{array}$ & $\begin{array}{l}\text { Volatile } \\
\text { matter }\end{array}$ & $\begin{array}{l}\text { Fixed } \\
\text { carbon }\end{array}$ & $\begin{array}{l}\text { Ash con- } \\
\text { tent }\end{array}$ & References \\
\hline KFB & 3.4 & 17.5 & 56.4 & 22.7 & {$[10]$} \\
KB & - & 25.9 & 67.5 & 6.6 & {$[24]$} \\
\hline
\end{tabular}

Table 7 Mineral composition of the biochars obtained at different temperatures $(\mathrm{g} / \mathrm{kg})$

\begin{tabular}{lllll}
\hline Element (wt\%) & \multicolumn{2}{l}{ Kenaf biochars } & Other biochars \\
\cline { 2 - 4 } & {$[24]$} & {$[57]$} & {$[55]$} & {$[65-67]$} \\
\hline $\mathrm{Na}$ & 2.4 & 0.1 & - & $1-5$ \\
$\mathrm{Mg}$ & 10.3 & 0.6 & 0.4 & $0-2$ \\
$\mathrm{Al}$ & 0.5 & 0.03 & - & - \\
$\mathrm{Si}$ & 0.8 & 0.1 & - & - \\
$\mathrm{P}$ & 1.3 & 0.16 & - & $0.1-2$ \\
$\mathrm{~S}$ & 1.5 & 0.08 & 0.6 & - \\
$\mathrm{Cl}$ & 0.2 & - & 0.4 & - \\
$\mathrm{K}$ & 7.3 & 0.64 & 4.2 & $2-10$ \\
$\mathrm{Ca}$ & 6.8 & 0.53 & 0.7 & $5-20$ \\
$\mathrm{Fe}$ & 0.3 & - & - & - \\
$\mathrm{Zn}$ & 2.3 & - & - & - \\
$\mathrm{Sr}$ & 0.1 & - & - & - \\
$\mathrm{N}$ & - & - & - & $0-1$ \\
$\mathrm{O}$ & - & - & 14.0 & - \\
\hline
\end{tabular}

textural characteristics of the kenaf biochars. The observed values are rather high, which is a significant benefit for using kenaf biochars to remove contaminants from effluents. The kenaf biochars' specific surface area was estimated using the BET technique and $\mathrm{CO}_{2}$ adsorption isotherms. According to Khiari et al. [24], the surface area of the produced biochar increased considerably from 162 to $261 \mathrm{~m}^{2} / \mathrm{g}$ as the pyrolysis temperature increased. This progression is explained by a change in the textural characteristics of the biochars, which can be related to the minor devolatilization observed between 400 and $500{ }^{\circ} \mathrm{C}$, which creates more microporosity in the carbon matrix. In addition, greater temperatures appear to influence the porosity of the char [16].

The surface of the biochars grew rougher and more porous as the pyrolysis temperature high. The organic component of pyrolyzed kenaf at high temperatures vanished owing to devolatilization/decomposition, resulting in pyrolyzed kenaf with a rough surface [9]. Cho et al. [55] observed that when the pyrolysis temperature increased, the specific surface area of kenaf biochar grew dramatically from 5 to $270 \mathrm{~m}^{2} / \mathrm{g}$, which is improved $>65$ times, and even the porosity of kenaf biochar enhanced. Previous studies [2, $69,70]$ has also found that when the pyrolysis temperature rises, the specific surface area increases by more than tenfold. The liberation of volatile organic chemicals and the oxidative breaking of cellulose, hemicellulose, and lignin are due to the rise in specific surface area caused by pyrolysis temperature increase [55]. Furthermore, inside the biochar that was pyrolyzed at high temperatures, a complex pore structure with a rough surface was discovered as a result of dissolving the unstable component and softening the stable structure in biomass, which resulted in shrinkage, collapse, and melting of the pore [71].

3.2.1.4 Raman Spectroscopy Raman spectroscopy is used to determine phase and polymorphisms, as well as pollution and impurities. Figure 8 depicts Raman spectrometry curves from this investigation by Khiari et al. [24]. The Raman spectra at $400{ }^{\circ} \mathrm{C}$ showed a signal with no discernible peaks, which was attributable to the high amount of amorphous carbon structures generated at low pyrolysis temperatures. The Raman spectra at $500{ }^{\circ} \mathrm{C}$ showed two relatively large 


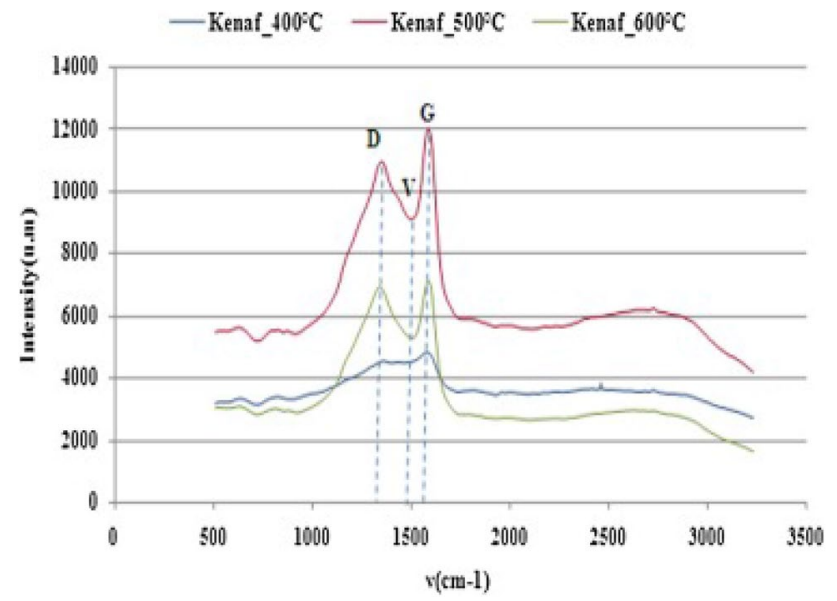

Fig. 8 Raman spectra of the kenaf biochar produced at 400, 500 and $600{ }^{\circ} \mathrm{C}[24]$

Raman bands at 1300 and $1600 \mathrm{~cm}^{-1}$. The D-band is associated with $\mathrm{sp}^{2}$ bonded carbon with structural flaws, whereas the G-band is associated with the in-plane vibrations of $s p^{2}$ bonded graphitic carbon structures. The valley area "V" between the D-band and the G-band is connected to the amorphous carbon structure. Structure characteristics such as $I_{D}$ (D band intensity height), $I_{G}$ ( $G$ band intensity height), $I_{V}$ (valley region intensity height) and the distinct ratios $I_{D} /$ $\mathrm{I}_{\mathrm{G}}, \mathrm{I}_{\mathrm{V}} / \mathrm{I}_{\mathrm{G}}$, and $\mathrm{I}_{\mathrm{V}} / \mathrm{I}_{\mathrm{D}}$ have been computed from these spectra in order to obtain detailed information on the structure of the individual chars [24].

The $\mathrm{I}_{\mathrm{V}} / \mathrm{I}_{\mathrm{D}}$ and $\mathrm{I}_{\mathrm{V}} / \mathrm{I}_{\mathrm{G}}$ ratio decreases due to the char evolution structure with pyrolysis severity from amorphous to more organized carbon (turbostratic char). As for $\mathrm{I}_{\mathrm{D}} / \mathrm{I}_{\mathrm{G}}$, this ratio decreases indicating an increase of the proportion of condensed aromatic ring structures having defects. Condensation of tiny aromatic amorphous carbon structures results in D structures. These findings are consistent with the results observed for exhausted grape marc char after various thermal treatments [72], see Fig. 9. This behavior can be due to the significant amount of amorphous carbon structures formed during low-temperature pyrolysis [57]. The Raman spectra above $500{ }^{\circ} \mathrm{C}$ showed two reasonably wide Raman bands. The other biochar has a similar tendency. This behaviour may be described by the char evolution structure with the severity of pyrolysis from amorphous carbon to structured carbon (turbostratic char).

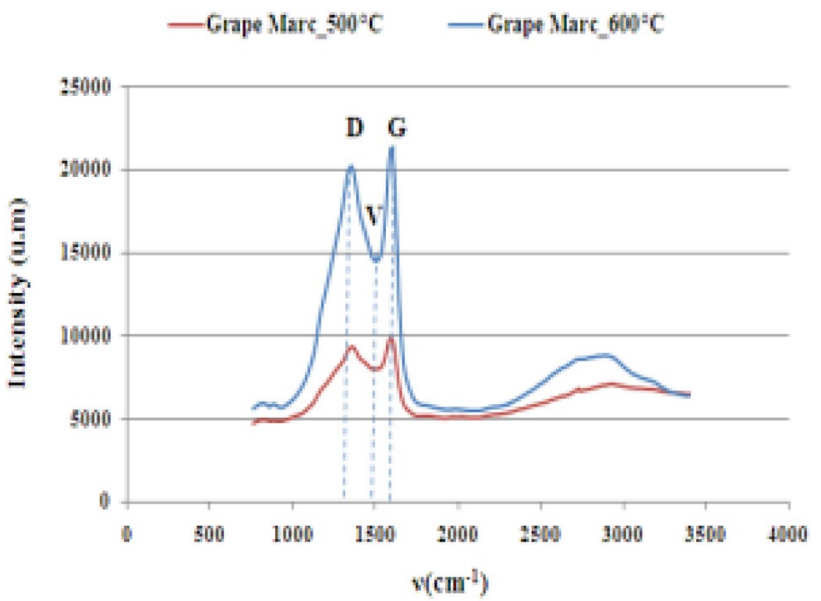

Fig. 9 Raman spectra of the grape marc biochars produced at different temperature [57]

\section{Recent Applications of Kenaf Biochar and Its Composites}

\subsection{Materials Adsorbents for Wastewater Treatments}

Lacks in wastewater treatment happened when there are no alternatives in purifying and treating the sludge prior to disposal. Sludge with a high concentration of heavy metals such as $\mathrm{Fe}, \mathrm{Ti}, \mathrm{Mn}, \mathrm{Zn}, \mathrm{As}, \mathrm{Cu}, \mathrm{Ni}, \mathrm{Zr}$, and $\mathrm{Ga}$ is often disposed of in landfills [11]. The recovery of valuable minerals like manganese from sludge is an alternative to zero disposal of solid wastes and a means to reduce pollution emission into the environment. It may be accomplished by adsorption, which is a low-cost, versatile, and simple-to-implement technique. Kenaf derived biochar which then chemically activated into activated carbon has been shown to be an excellent adsorbent material for heavy metals removal. The goal of this research is to use kenaf fibre as activated carbon in batch adsorption to recover heavy metals from wastewater sludge. The adsorption effectiveness of adsorbents was studied in relation to contact time, sludge $\mathrm{pH}$, and temperature as well as its surface area and pore properties. The results indicated that the newly produced kenaf activated carbon and biochar are the most possible alternative adsorbents for heavy metals [50].

According to a batch adsorption research [13], kenaf fibre-derived activated carbon is capable of removing $30 \%$ of the heavy metal element from the sludge. It was also discovered that the optimum removal occurs in a neutral $\mathrm{pH}$ solution, that increasing contact duration increases equilibrium absorption, and that raising temperature increases the amount of heavy metal removal [13]. The development of heavy metal removal methods for aquatic environments is in great demand. Saeed et al. [10] had 
investigated the pyrolysis of raw materials including rice husk and kenaf fibre as agricultural lignocellulosic wastes for the adsorption of $\mathrm{Cu}^{2+}$. The surface area of biochar produced increases proportionately to the increasing quantity of kenaf fibre in the mixing ratio rice husk/kenaf fibre as biomass feedstocks, according to BET characterization findings. This morphology and surface area analysis revealed that pure biochars made from kenaf fibre had a lot of promise as adsorbents. However, blending both fibres does not provide the intended outcome for utilization as an adsorbent, which has a detrimental impact on biochar production since the oxygen-to-carbon and hydrogen-tocarbon ratios were outside the usual range, affecting biochar stability. As a result, it impacted copper ion adsorption from aqueous solutions [10].

In another work from Saeed et al. [61], the adsorption study on cadmium materials had resulted with optimum adsorption under $\mathrm{pH} 5-6$. The textural characteristics of biochars, such as surface area and pore volume, were improved by increasing the amount of oxygen-containing groups and creating inner-sphere complexes with oxygencontaining groups. Increased adsorption capacity was achieved by increasing the initial ion concentration and solution temperature. The use of iron oxide on the surface of biochar to impart a magnetic characteristic allowed for simple separation and regeneration using an external magnet. In comparison to pure biochar, the magnetic biochar composite had a greater affinity for $\mathrm{Cd}^{2+}$. By acid treating kenaf fibre biochar with $\mathrm{HCl}$, an adsorbent was created. In batch system experiments, the treatment increased the BET surface area, which resulted in an increase in the adsorption of methylene blue dye (MB). Variations in the initial dye concentration, adsorbent dosage, $\mathrm{pH}$, and temperature were used to examine the adsorption process. At a concentration of $50 \mathrm{mg} / \mathrm{L}$, the greatest percentage removal of MB was determined to be $95 \mathrm{wt} \%$. The dye sorption was optimal at a $\mathrm{pH}$ of 8.5 [32].

\subsection{Soil Amendments in Agriculture}

Ferjani et al. [57] studied three agricultural biomass including grape marc, kenaf stems, and flax shive, for biochar production. For a future possible application in agriculture, the pyrolysis operation was carried out at 400,500 , and $600{ }^{\circ} \mathrm{C}$ with a continuous heating gradient rate of $5{ }^{\circ} \mathrm{C} / \mathrm{min}$. The biochar yields declined as the applied pyrolysis temperature increased, but remained relatively stable at $500{ }^{\circ} \mathrm{C}$ for all feedstocks, according to the results. Grape marc and kenaf contain the largest quantity of theoretically accessible minerals, as well as an intriguing surface area and microporosity value, according to their physico-chemical characteristics [57]. These characteristics make biochars excellent for soil improvements and the adsorption of contaminants from environment.

Yao et al. [73] had successfully investigated the utilization of biochar derived from $\mathrm{Mg}$-enriched tomato tissues in order to adsorb and recover phosphate from wastewater, which was then cycled back into grounds as an efficient slow-release phosphate fertilizer. According to Vithanage et al. [74], acid treatment enhanced the specific surface area of bur-cucumber derived biochar, exhibit better sulfamethazine adsorption ability and should be utilized as possible soil bioremediation suitable for sulfamethazine-polluted soils.

\subsection{Electrochemical Applications of Kenaf Biochar}

Biochar has been utilized as an electro catalyst and photo catalyst in the electrochemical water-splitting process to produce hydrogen and oxygen $[75,76]$. The addition of a heteroatom produces active sites in biochar, allowing for a more efficient hydrogen evolution process (HER). S-doped and $\mathrm{N}$-doped biochars produced from peanut root nodule (see Fig. 10), for example, have been shown to be effective HER electro catalysts. Because of its large electrochemical area of $27.4 \mathrm{mF} / \mathrm{cm}^{2}$, the doped biochar demonstrated an (a)
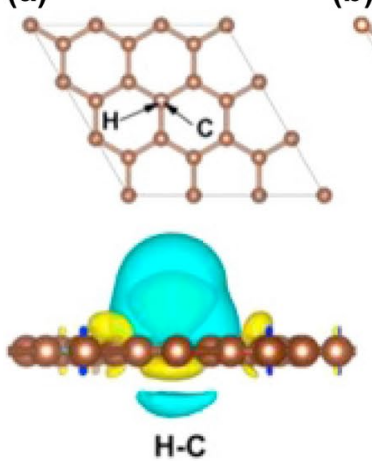

(b)

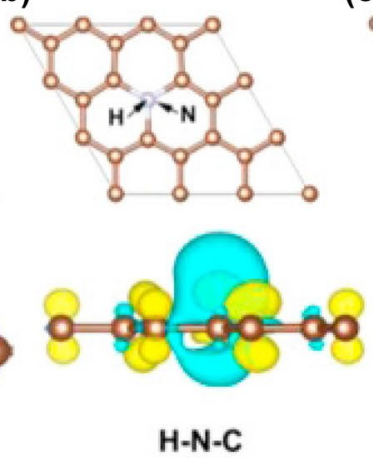

(c)

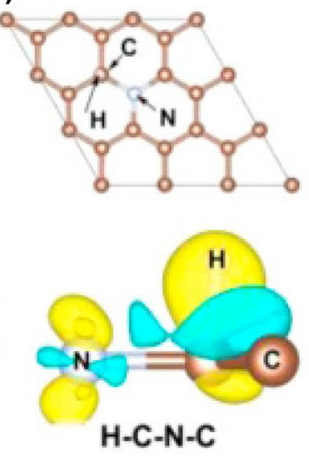

(d)
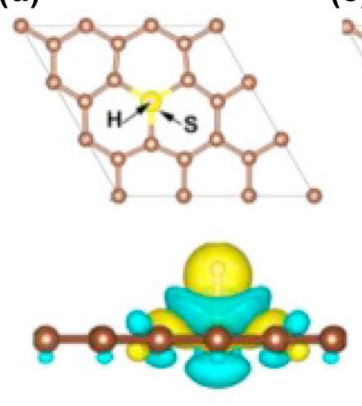

H-S-C (e)

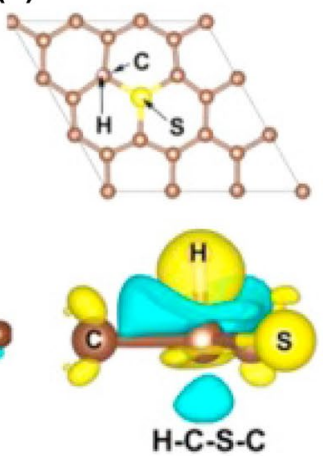

Fig. 10 Structural models and charge density of $\mathrm{H}$ adsorbed on the surface of graphene, $\mathrm{N}$-doped graphene and S-doped graphene. The blue and yellow symbols represent a drop in charge density and a rise in charge density, respectively 
outstanding onset potential of $27 \mathrm{mV}$ compared to reversible hydrogen electrode (RHE) for HER, which is similar to a commercial Pt/C catalyst with a loading of $20 \mathrm{wt} \%$ [77]. Figure 10 shows the effect of $\mathrm{S}$ and $\mathrm{N}$ doping into carbon on HER. The flowing process was as follows: (a) $\mathrm{H}$ atom was combined on the $\mathrm{C}$ atom; $\mathrm{H}$ atom was combined on the $\mathrm{N}$ (b) or $\mathrm{S}$ (d) dopant atom; $\mathrm{H}$ atom was combined on the $\mathrm{C}$ atom around $\mathrm{N}$ (c) or S (e) dopant atom.

Nanostructure catalysts made from sunflower seed shell charcoal and molybdenum carbide $\left(\mathrm{Mo}_{2} \mathrm{C}\right)$ nanoparticles are another example. At an over potential of only $60 \mathrm{mV}$, this integrated electro catalyst produced a current density of $10 \mathrm{~mA} \mathrm{~cm}{ }^{2}$ for HER. Most notably, this catalyst has a near-unity faradaic efficiency and is extremely durable [78]. Growth of molybdenum diselenide $\left(\mathrm{MoSe}_{2}\right)$ nanosheets on a carbon fibre aerogel is another example. Cotton wool biomass was used to make the carbon aerogel. At an onset potential of $104 \mathrm{mV}$, this $\mathrm{MoSe}_{2} /$ carbon fibre electro catalyst demonstrated HER vs RHE [79]. Without a doubt, current biochar catalyst performance lags well below that of the most effective water-splitting catalysts, with over-potentials of 13 and $17 \mathrm{mV}$ at a current density of $10 \mathrm{~mA} / \mathrm{cm}^{2}$ [80]. It does, however, have the potential to be employed as an abundant alternative catalyst material for the generation of hydrogen and oxygen.

The utilization of biomass waste materials to manufacture activated carbons has become a huge technology in carbon supercapacitor electrodes [81, 82]. Various kind of agricultural biomass including cotton stalks [83], discarded coffee beans [84], seaweed biopolymers [85], corn stovers [86], roselle [87, 88], and sugarcane bagasse [89] have all been reported as carbon electrodes in supercapacitors. The carbon precursor and modification circumstances utilised ascertain the electrochemical attributes of double-layer capacitance, including such high surface area, porosity distribution, conductivity, as well as the existence of electrochemically active surface functional groups, and hence impact the performance $[82,90]$. Because of their enormous surface areas, relative inertness, and abundant possibilities for doping and structural tweaking, carbons generated from biomass play such an important role in electrochemistry [91].

\subsection{Horticultural Applications}

Biochars may be utilized in a variety of horticultural applications, such as replacing peat moss on soilless substrates for containerized greenhouse and nursery crops. Hardwood pellets and pelletized wheat straw were used to make biochar via pyrolysis as shown in Fig. 11. The potassium concentration and $\mathrm{pH}$ of straw biochar were greater than those of wood biochar [46]. In comparison to non-activated biochar, steam activation of biochar might hasten its beneficial effects on nutrient retention and uptake by plants. In all cases, steam

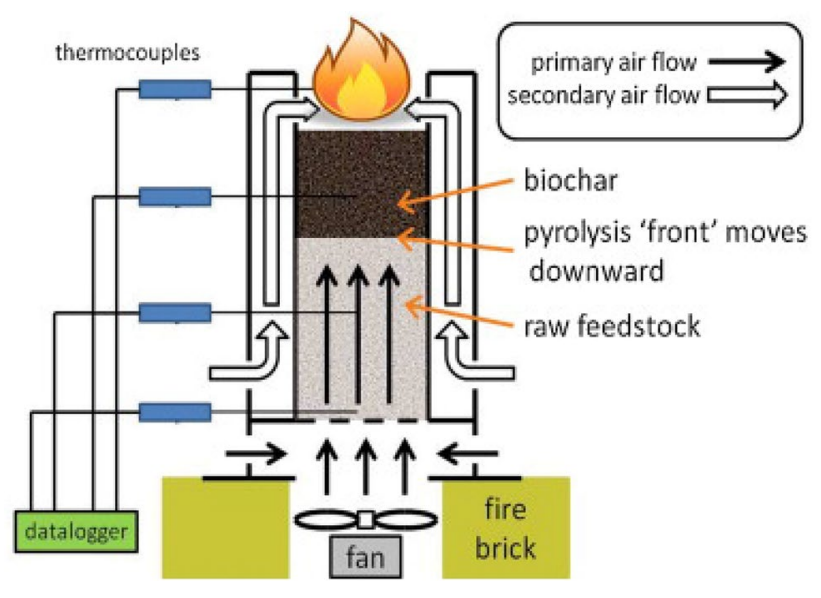

Fig. 11 Schematic illustrations of thermal decomposition of raw biomass [46]

activation almost doubled the beneficial benefits of biochars, making it a promising choice in order to use biochar in future [92]. After modification, biochars' adsorption ability of nitrate and phosphate improves, implying that activated biochars could also be used as adsorbent materials to reduce nutrient loss in grounds and for further horticultural purposes [93] (Table 8).

\subsection{Future Directions of Kenaf Biochar in Composite Applications}

There is difficult to find any published works on kenaf derived biochar uses in composite applications. However, it is remarkably found that the surface area (approximately $120-300 \mathrm{~m}^{2} / \mathrm{g}$ ) and micropore volumes (over $0.088 \mathrm{~cm}^{3} / \mathrm{g}$ ) of kenaf biochar is quite similar to the other commercialised biochars such as durian rind, sugarcane bagasse, rice straw and corn straw, as according to previous works [10, 24, 31]. Thus, numerous applications could be found in composite engineering with the contribution from distinct characteristics of kenaf biochar based composites including production of magnetic biochar for low-cost supercapacitor application [94], low-price novel engineered adsorbents [95], biochar composite-based catalysts [96], bacterial/biochar composites for bioremediation [97], and antibacterial composite for water treatment [98].

Despite the difficulties in finding research work on kenaf biochar uses in composites engineering, biochar derived from other biomass feedstocks had been widely commercialised as reported in literature. Matykiewicz [99] had fabricated carbon fibre reinforced biochar/epoxy composites for mechanical reinforcements. From the results, the mechanical and thermal properties of the biochar reinforced composites improved by almost $5 \%$ compared to the neat one. Das et al. [100] had utilized biochar originated from pine wood waste 
Table 8 Current application of kenaf and other biomass derived biochar in various applications

\begin{tabular}{|c|c|c|c|c|}
\hline Biochar & Applications & Uses & Key points & References \\
\hline Kenaf biochar & Wastewater treatments & $\mathrm{Cd}^{2+}$ adsorbents & $\begin{array}{l}\text { Optimum adsorption achieved under } \\
\text { pH 5-6 } \\
\text { Surface modification of biochar } \\
\text { using iron oxide for impos- } \\
\text { ing magnetic property allowed } \\
\text { for easy separation by external } \\
\text { magnet and regeneration, with the } \\
\text { maximum adsorption capacity of } \\
47.90 \mathrm{mg} / \mathrm{g}\end{array}$ & {$[61]$} \\
\hline $\begin{array}{l}\text { Kenaf fibre activated carbon } \\
\text { (KFAC) }\end{array}$ & Sludge treatment & Heavy metals adsorbents & $\begin{array}{l}\text { BET surface area-11.4 } \\
\mathrm{m}^{2} / \mathrm{g} ; \text { micropore vol- } \\
\text { ume- }-0.1072-0.2169 \mathrm{~cm}^{3} / \mathrm{g} ; \\
\text { cumulative adsorption area-210- } \\
600 \mathrm{~m}^{2} / \mathrm{g}\end{array}$ & [13] \\
\hline Kenaf biochar & Wastewater treatments & $\mathrm{Cu}^{2+}$ adsorbents & $\begin{array}{l}\text { BET surface area-400-500 } \\
\mathrm{m}^{2} / \mathrm{g} ; \text { pore volume }-0.017 \\
\mathrm{~cm}^{3} / \mathrm{g} ; \text { removal efficiency of } \\
\mathrm{Cu}^{2+}-12.30 \%\end{array}$ & {$[10]$} \\
\hline Rice husk biochar & Wastewater treatments & $\mathrm{Cu}^{2+}$ adsorbents & $\begin{array}{l}\text { The rice husk biochar showed } \\
\text { good adsorption of copper ions } \\
\text { from aqueous solutions. BET } \\
\text { surface area- }-13.6 \mathrm{~m}^{2} / \mathrm{g} \text {; pore } \\
\text { volume- }-0.0076 \mathrm{~cm}^{3} / \mathrm{g} \text {; removal } \\
\text { efficiency of } \mathrm{Cu}^{2+}-65.80 \%\end{array}$ & {$[10]$} \\
\hline Kenaf fibre biochar & Agriculture & Soil amendments & $\begin{array}{l}\text { KF has the most theoretically acces- } \\
\text { sible minerals, as well as an attrac- } \\
\text { tive surface area }\left(261.2 \mathrm{~m}^{2} / \mathrm{g}\right) \text { and } \\
\text { microporosity value }\end{array}$ & {$[57]$} \\
\hline P-laden biochar & Agriculture & Slow-release fertilizer & $\begin{array}{l}\text { Maximum P sorption capacity of } \\
\text { the biochar }->100 \mathrm{mg} / \mathrm{g}\end{array}$ & [73] \\
\hline Burcucumber biochar & Agriculture & Soil amendments & $\begin{array}{l}\text { Acid activation showed enhanced } \\
\text { sorption of Sulfamethazine (SMZ) } \\
\text { Activated biochar has BET surface } \\
\text { area of } 571 \mathrm{~m}^{2} / \mathrm{g} \\
\text { The predicted maximum equilib- } \\
\text { rium concentration of biochar for } \\
\text { loamy sand soils was } 182 \mathrm{mg} / \mathrm{kg}\end{array}$ & {$[74]$} \\
\hline MoP/biomass carbon flake & Electrochemistry & Electrocatalysts & $\begin{array}{l}\text { Highly active HER electrocatalyst } \\
\text { with excellent durability in acidic } \\
\text { electrolytes }\end{array}$ & {$[76]$} \\
\hline Sugarcane bagasse biochar & Electrochemistry & Electrochemical capacitance & $\begin{array}{l}\text { High specific capacitance of } 280 \\
\mathrm{Fg}^{-1} \text { at a current density of } 1 \mathrm{~A} / \mathrm{g} \\
72 \% \text { retention at a very high current } \\
\text { density of } 20 \mathrm{~A} / \mathrm{g} \\
\text { Good energy density of } 5 \mathrm{Wh} / \mathrm{kg} \text { at } \\
\text { a power density of } 3.5 \mathrm{~kW} / \mathrm{kg}\end{array}$ & [89] \\
\hline $\begin{array}{l}\text { Peanut root nodules derived carbon } \\
\text { nanosheets }\end{array}$ & Electrochemistry & Non-metal catalysts & $\begin{array}{l}\mathrm{S} \text { and } \mathrm{N} \text {-doped carbons exhibit a } \\
\text { porous and multilayer structure } \\
\text { with a specific surface area of } \\
513.3 \mathrm{~m}^{2} / \mathrm{g} \text { and high electrochemi- } \\
\text { cal area of } 27.4 \mathrm{mF} / \mathrm{cm}^{2}\end{array}$ & {$[77]$} \\
\hline Corn stover biochar & Super capacitor & Carbon electrode & $\begin{array}{l}\text { High specific capacitance of } 245.9 \\
\mathrm{Fg}^{-1} \text { at a current density of } 0.1 \\
\mathrm{~A} / \mathrm{g}\end{array}$ & {$[86]$} \\
\hline $\begin{array}{l}\text { Cotton stalks derived activated } \\
\text { carbon }\end{array}$ & Super capacitor & Electric double-layer capacitor & $\begin{array}{l}\text { Activated carbon with a BET } \\
\text { surface area of } 1.481 \mathrm{~cm}^{2} / \mathrm{g} \text { and } \\
\text { micropore volume of } 0.0377 \\
\mathrm{~cm}^{3} / \mathrm{g} \\
\text { The capacitance is } 114 \mathrm{Fg}^{-1}\end{array}$ & {$[83]$} \\
\hline
\end{tabular}


Table 8 (continued)

\begin{tabular}{|c|c|c|c|c|}
\hline Biochar & Applications & Uses & Key points & References \\
\hline Waste coffee beans derived carbon & Super capacitor & Nanoporous carbon electrode & $\begin{array}{l}\text { The energy densities up to } 20 \mathrm{Wh} / \\
\mathrm{kg} \text { in } 1 \mathrm{M} \mathrm{H}_{2} \mathrm{SO}_{4} \text {, with excellent } \\
\text { stability at high charge-discharge } \\
\text { rates } \\
\text { The two-electrode cell has capaci- } \\
\text { tance of } 368 \mathrm{Fg}^{-1} \\
\text { Stable performance over } 10,000 \\
\text { cycles at a cell potential of } 1.2 \mathrm{~V} \\
\text { and current load of } 5 \mathrm{~A} / \mathrm{g} \\
\text { The distribution of micropores and } \\
\text { mesopores } 2-4 \mathrm{~nm} \text { wide }\end{array}$ & {$[84]$} \\
\hline Wheat straw biochar & Horticulture & Potting substrates & $\begin{array}{l}\mathrm{pH}-5.8 \text {, container capac- } \\
\text { ity-65.6\%, total porosity- } 89.8 \% \\
\text { Greenhouse experiments using } \\
\text { tomato and marigold plants grown } \\
\text { in } 3.0-\mathrm{L} \text { pots showed positive } \\
\text { results }\end{array}$ & [46] \\
\hline Beech wood biochar & Horticulture & Soil fertilizer & $\begin{array}{l}\text { Biochar applications of } 15 \mathrm{~g} / \mathrm{kg} \text { soil } \\
\text { resulted in higher levels of acces- } \\
\text { sible } \mathrm{P} \text { and } \mathrm{N} \text { in the surface soil }\end{array}$ & [92] \\
\hline
\end{tabular}

as reinforcement agents within polypropylene matrix, the biochar exhibits comparable carbon content of $82 \mathrm{wt} \%$ and specific surface area, $335 \mathrm{~m}^{2} / \mathrm{g}$, as of kenaf biochar. Thus, large surface area of the engineered biochar allowed polypropylene to flow, resulting in mechanical interlocking and improved mechanical characteristics $[11,101]$.

Conclusively, biochar should be used in biocomposites to increase its usefulness and generate better composites while also managing waste in a sustainable manner [102]. However, no research including kenaf derived biochar in biocomposites have been done so far. As a result, this opinion may encourage researchers to investigate the use of the biochar in biocomposites.

\section{Conclusion and Future Propects}

In this paper, current developments of kenaf-derived biochar and its composites in engineering and agricultural applications, such as nanostructure catalysts and polymer composites, had been discussed. Kenaf biochar and activated carbon are mostly utilized as soil amendments and material adsorbents, and they are yet to be utilized in other engineering applications such as biocomposites, supercapacitors and optical applications. Thus, thorough literature review on the influence of process parameters of thermal decomposition, pyrolysis, and biochar formation on the manufacture of desired biochar is critical. This review had been focused on the unique characteristics of kenaf crops and the resulting biochar, which has a surprisingly large surface area and increased pore volume, in order to explain their prospective use, whether in environmental or technical applications. Recent advances in engineered kenaf biochar technology, as well as future research and development directions, were briefly highlighted. As a result of the preceding debate, it is obvious that low-cost, environmentally friendly, green, and facile processing products must be taken into account for solving current environmental issues toward sustainable environment in the future. Thus, it is paramount to create approaches and products that (1) reduce the usage of fossil fuels, (2) recycling trash, and (3) are biodegradable plus environmentally friendly.

Kenaf biochar promises to be a novel potentially costeffective and ecologically friendly carbon material with a wide range of applications. Despite the fact that current research on the manufacture and application of activated biochar in a variety of fields is expanding [103], a number of research gaps still exist. The following ideas are suggested to alleviate these gaps in knowledge:

(i) The characteristics of activated biochar may be considerably affected by feedstock with varied compositions, manufacturing circumstances, and activation parameters of biochar. Future research will be required to select feedstock with acceptable compositions, as well as optimize production circumstances and activation parameters, in order to create biochar with appropriate and intended characteristics for specific uses.

(ii) More relevant and innovative treatments for activation, as well as improvements to existing techniques, are required. Furthermore, using multiple main activation methods for biochar activation may give a 
good opportunity to improve activation efficiency by integrating the benefits of diverse approaches.

(iii) The majority of biochar applications are focused on water pollution remediation, whereas applications for $\mathrm{CO}_{2}$ capture and energy storage are comparatively underutilized and should be broadened. Furthermore, there are several possible applications for activated biochar that should be studied in the future. It might be utilized as a novel possible in-situ amendment for polluted soil and sediment management, for example.

(iv) For future practical engineering applications of biochar, more research are required to gain insight into the issues surrounding its large-scale manufacturing, scaled-up application, stability, reuses, and wasted biochar management.

Acknowledgements The author gratefully acknowledged Ministry of Higher Education (MoHE) for funding this project via Post COVID19 Special Research Grant 2020 (Vote No. 5540346), University of Minho, Portugal for the invitation to present the similar finding, and also Universiti Putra Malaysia for providing research facilities. Special thanks as well for Mohamed Mehdi Chehimi, Executive Editor-inChief of Chemistry Africa, for the publication invitations.

\section{References}

1. Demiral İ, Kul ŞÇ (2014) Pyrolysis of apricot kernel shell in a fixed-bed reactor: characterization of bio-oil and char. J Anal Appl Pyrolysis 107:17-24

2. Harussani MM, Sapuan SM, Khalina A, Rashid U, Tarique J (2021) Slow pyrolysis of disinfected COVID-19 non-woven polypropylene (PP) waste. In: Int. Symp. Appl. Sci. Eng. ISASE2021. Office of International Affairs, Atatürk University, Erzurum, Turkey, pp 310-312

3. Faaij APC (2004) Biomass combustion. pp 175-191

4. Taylor CS, Kugler DE (1992) Kenaf: annual fiber crop products generate a growing response from industry. USDA publications 92-98. https://handle.nal.usda.gov/10113/IND93048063

5. Lee $\mathrm{CH}$, Khalina A, Nurazzi NM, Norli A, Harussani MM, Rafiqah S, Aisyah HA, Ramli N (2021) The challenges and future perspective of woven kenaf reinforcement in thermoset polymer composites in Malaysia: a review. Polymers (Basel) 13:1390

6. Dempsey JM (1975) Fiber crops. University Press of Florida, Gainesville

7. Norizan MN, Moklis MH, Alias AH, Rushdan AI, Norrrahim MNF, Abdan K, Abdullah N (2021) Treatments of natural fibre as reinforcement in polymer composites-short review. Funct Compos Struct. https://doi.org/10.1088/2631-6331/abff36

8. Xu J, Tao A, Qi J, Wang Y (2020) Bast fibres: kenaf. In: Handbook of natural fibres. Woodhead Publishing, $p$ 71-92

9. Saba N, Jawaid M, Hakeem KR, Paridah MT, Khalina A, Alothman OY (2015) Potential of bioenergy production from industrial kenaf (Hibiscus cannabinus L.) based on Malaysian perspective. Renew Sustain Energy Rev 42:446-459

10. Saeed AAH, Harun NY, Sufian S, Afolabi HK, Al-Qadami EHH, Roslan FAS, Rahim SA, Ghaleb AAS (2021) Production and characterization of rice husk biochar and Kenaf biochar for value-added biochar replacement for potential materials adsorption. Ecol Eng Environ Technol 22(1):1-8. https://doi.org/ 10.12912/27197050/132099

11. Harussani MM, Sapuan SM, Khalina A, Ilyas RA, Hazrol MD (2020) Review on green technology pyrolysis for plastic wastes. In: Proceedings of 7th Postgrad. Semin. Nat. Fibre Reinf. Polym. Compos. 2020. Institute of Tropical Forest and Forest Products (INTROP), Universiti Putra Malaysia, Serdang, Selangor, pp $50-53$

12. Basu P (2013) Chapter 4 Torrefaction. In: Biomass gasification, pyrolysis and torrefaction: Practical design and theory. Academic Press, p 87-145. https://doi.org/10.1016/C2011-0-07564-6

13. Saeed AAH, Harun NY, Zulfani N (2020) Heavy metals capture from water sludge by kenaf fibre activated carbon in batch adsorption. J Ecol Eng 21(6):102-115. https://doi.org/10.12911/ 22998993/123249

14. Norizan MN, Harussani MM, Demon SZN, Halim NA, Samsuri A, Mohamad IS, Knight VF, Abdullah N (2020) Carbon nanotubes: functionalisation and their application in chemical sensors. RSC Adv 10:43704-43732

15. Mohd Nurazzi N, Muhammad Asyraf MR, Khalina A et al (2021) Fabrication, functionalization, and application of carbon nanotube-reinforced polymer composite: an overview. Polymers (Basel) 13:1047

16. Nasir HM, Aris AZ, Abdullah LC, Ismail I (2021) Facile fabrication and characterization of kenaf core as natural biochar for the highly efficient removal of selected endocrine-disrupting compounds. Environ Geochem Health 1-21. https://doi.org/10. 1007/s10653-021-00999-8

17. Laird DA (2008) The charcoal vision: a win-win-win scenario for simultaneously producing bioenergy, permanently sequestering carbon, while improving soil and water quality. Agron J 100:178-181

18. Tian Y, Sun X, Li S, Wang H, Wang L, Cao J, Zhang L (2012) Biochar made from green waste as peat substitute in growth media for Calathea rotundifola cv. Fasciata Sci Hortic (Amsterdam) 143:15-18

19. Schulz H, Glaser B (2012) Effects of biochar compared to organic and inorganic fertilizers on soil quality and plant growth in a greenhouse experiment. J Plant Nutr Soil Sci 175:410-422

20. Hussain R, Ravi K, Garg A (2020) Influence of biochar on the soil water retention characteristics (SWRC): potential application in geotechnical engineering structures. Soil Tillage Res 204:104713

21. Dai Y, Zhang N, Xing C, Cui Q, Sun Q (2019) The adsorption, regeneration and engineering applications of biochar for removal organic pollutants: a review. Chemosphere 223:12-27

22. Godwin PM, Pan Y, Xiao H, Afzal MT (2019) Progress in preparation and application of modified biochar for improving heavy metal ion removal from wastewater. J Bioresour Bioprod 4:31-42

23. Harussani MM, Sapuan SM, Rashid U, Khalina A (2021) Development and characterization of polypropylene waste from personal protective equipment (PPE)-derived char-filled sugar palm starch biocomposite briquettes. Polymers (Basel) 13:1707

24. Khiari B, Ghouma I, Ferjani AI, Azzaz AA, Jellali S, Limousy L, Jeguirim M (2020) Kenaf stems: thermal characterization and conversion for biofuel and biochar production. Fuel 262:116654

25. Idan IJ, Abdullah LC, Choong TSY, Jamil SNABM (2018) Equilibrium, kinetics and thermodynamic adsorption studies of acid dyes on adsorbent developed from kenaf core fiber. Adsorpt Sci Technol 36:694-712

26. Sgriccia N, Hawley MC, Misra M (2008) Characterization of natural fiber surfaces and natural fiber composites. Compos Part A Appl Sci Manuf 39:1632-1637

27. Wahab M, Sapuan SM, Harussani MM, Zuhri MYM, Saleh AA (2021) Conceptual design of glass/renewable natural 
fibre-reinforced polymer hybrid composite motorcycle side cover. J Renew Mater 9:1973-1989

28. Webber CL III, Bledsoe VK, Bledsoe RE, Janick J, Whipkey A (2002) Kenaf harvesting and processing. Trends New Crop New Uses 9:340-347

29. Coetzee R (2004) Characterization of kenaf (Hibiscus cannabinus L.) cultivars in South Africa

30. Sapuan SM, Pua F, El-Shekeil YA, AL-Oqla FM (2013) Mechanical properties of soil buried kenaf fibre reinforced thermoplastic polyurethane composites. Mater Des 50:467-470

31. Yusof JM, Salleh MAM, Rashid SA, Ismail I, Adam SN (2014) Characterisation of carbon particles (CPs) derived from dry milled kenaf biochar. J Eng Sci Technol Special Issue on Applied Engineering and Sciences:125-131

32. Dalia KM, Mohamad A, Wan A, Azni I, Zurina ZA (2012) Batch adsorption of basic dye using acid treated kenaf fibre char: equilibrium, kinetic and thermodynamic studies. Chem Eng $\mathbf{J}$ 181:449-457

33. Ramesh M (2016) Kenaf (Hibiscus cannabinus L.) fibre based bio-materials: a review on processing and properties. Prog Mater Sci 78:1-92

34. Nurazzi NM, Harussani MM, Zulaikha NDS, Norhana AH, Syakir MI, Norli A (2021) Composites based on conductive polymer with carbon nanotubes in DMMP gas sensors-an overview. Polimery 66:85-97

35. Tsakonas A, Stergiou V, Polissiou M, Akoumianakis K, Passam HC (2005) Kenaf (Hibiscus cannabinus L.) based substrates for the production of compact plants. Ind Crops Prod 21:223-227

36. Khiari B, Jeguirim M, Limousy L, Bennici S (2019) Biomass derived chars for energy applications. Renew Sustain Energy Rev 108:253-273

37. Gagliano A, Nocera F, Patania F, Bruno M, Scirè S (2016) Kinetic of the pyrolysis process of peach and apricot pits by TGA and DTGA analysis. Int J Heat Technol 34:S553-S560

38. Khalil HPSA, Yusra AFI, Bhat AH, Jawaid M (2010) Cell wall ultrastructure, anatomy, lignin distribution, and chemical composition of Malaysian cultivated kenaf fiber. Ind Crops Prod $31: 113-121$

39. Kuroda K, Izumi A, Mazumder BB, Ohtani Y, Sameshima K (2002) Characterization of kenaf (Hibiscus cannabinus) lignin by pyrolysis-gas chromatography-mass spectrometry in the presence of tetramethylammonium hydroxide. J Anal Appl Pyrolysis 64:453-463

40. Ververis C, Georghiou K, Christodoulakis N, Santas P, Santas R (2004) Fiber dimensions, lignin and cellulose content of various plant materials and their suitability for paper production. Ind Crops Prod 19:245-254

41. Nishimura N, Izumi A, Kuroda K (2002) Structural characterization of kenaf lignin: differences among kenaf varieties. Ind Crops Prod 15:115-122

42. Morrison Iii WH, Akin DE, Archibald DD, Dodd RB, Raymer PL (1999) Chemical and instrumental characterization of maturing kenaf core and bast. Ind Crops Prod 10:21-34

43. Tsoumis G (1991) Science and technology of wood: structure, properties, utilization. Van Nostrand Reinhold, New York

44. Ashori A, Nourbakhsh A, Tabrizi AK (2014) Thermoplastic hybrid composites using bagasse, corn stalk and E-glass fibers: fabrication and characterization. Polym Plast Technol Eng $53: 1-8$

45. Lam TBT, Hori K, Iiyama K (2003) Structural characteristics of cell walls of kenaf (Hibiscus cannabinus L.) and fixation of carbon dioxide. J Wood Sci 49:255-261

46. Vaughn SF, Kenar JA, Thompson AR, Peterson SC (2013) Comparison of biochars derived from wood pellets and pelletized wheat straw as replacements for peat in potting substrates. Ind Crops Prod 51:437-443
47. Inagaki M, Nishikawa $\mathrm{T}$, Sakuratani K, Katakura T, Konno H, Morozumi E (2004) Carbonization of kenaf to prepare highlymicroporous carbons. Carbon N Y 4:890-893

48. Moreira R, dos Reis OR, Vaz JM, Penteado JC, Spinacé EV (2017) Production of biochar, bio-oil and synthesis gas from cashew nut shell by slow pyrolysis. Waste Biomass Valoriz $8: 217-224$

49. Li S, Chan CY, Sharbatmaleki M, Trejo H, Delagah S (2020) Engineered biochar production and its potential benefits in a closed-loop water-reuse agriculture system. Water 12:2847

50. Saeed AAH, Harun NY, Sufian S, Bilad MR, Nufida BA, Ismail NM, Zakaria ZY, Jagaba AH, Ghaleb AAS, Al-Dhawi BNS (2021) Modeling and optimization of biochar based adsorbent derived from Kenaf using response surface methodology on adsorption of $\mathrm{Cd}^{2+}$. Water 13:999

51. Tee YB, Talib RA, Abdan K, Chin NL, Basha RK, Yunos KFM (2013) Thermally grafting aminosilane onto kenaf-derived cellulose and its influence on the thermal properties of poly (lactic acid) composites. BioResources 8:4468-4483

52. Leng L, Huang H (2018) An overview of the effect of pyrolysis process parameters on biochar stability. Bioresour Technol 270:627-642

53. Tripathi M, Sahu JN, Ganesan P (2016) Effect of process parameters on production of biochar from biomass waste through pyrolysis: a review. Renew Sustain Energy Rev 55:467-481

54. Pereira RC, Kaal J, Arbestain MC, Lorenzo RP, Aitkenhead W, Hedley M, Macías F, Hindmarsh J, Maciá-Agulló JA (2011) Contribution to characterisation of biochar to estimate the labile fraction of carbon. Org Geochem 42:1331-1342

55. Cho E-J, Kang J-K, Moon J-K, Um B-H, Lee C-G, Jeong S, Park S-J (2021) Removal of triclosan from aqueous solution via adsorption by kenaf-derived biochar: its adsorption mechanism study via spectroscopic and experimental approaches. J Environ Chem Eng 9:106343

56. Gan L, Fang X, Xu L, Wang L, Wu Y, Dai B, He W, Shi J (2021) Boosted activity of $\delta-\mathrm{MnO}_{2}$ by Kenaf derived carbon fiber for high-efficient oxidative degradation of bisphenol $\mathrm{A}$ in water. Mater Des 203:109596

57. Ferjani AI, Jeguirim M, Limousy L, Jellali S, Akrout H (2019) Biochar production from grape marc, kenaf stems and flax shives: effect of temperature on textural and physicochemical properties. In: 2019 10th Int. Renew. Energy Congr. IEEE, pp $1-4$

58. Aber S, Khataee A, Sheydaei M (2009) Optimization of activated carbon fiber preparation from Kenaf using $\mathrm{K}_{2} \mathrm{HPO}_{4}$ as chemical activator for adsorption of phenolic compounds. Bioresour Technol 100:6586-6591

59. Irmak S, Öztürk İ (2010) Hydrogen rich gas production by thermocatalytic decomposition of kenaf biomass. Int J Hydrogen Energy 35:5312-5317

60. Jeguirim M, Dorge S, Trouvé G (2010) Thermogravimetric analysis and emission characteristics of two energy crops in air atmosphere: Arundo donax and Miscanthus giganthus. Bioresour Technol 101:788-793

61. Saeed AAH, Harun NY, Sufian S, Bilad MR, Zakaria ZY, Jagaba AH, Ghaleb AAS, Mohammed HG (2021) Pristine and magnetic kenaf fiber biochar for $\mathrm{Cd}^{2+}$ adsorption from aqueous solution. Int J Environ Res Public Health 18:7949

62. Mahmoud DK, Salleh MAM, Karim WAWA, Idris A, Abidin ZZ (2012) Batch adsorption of basic dye using acid treated kenaf fibre char: equilibrium, kinetic and thermodynamic studies. Chem Eng J 181:449-457

63. Harussani MM, Sapuan SM, Rashid U, Khalina A, Ilyas RA (2021) Pyrolysis of polypropylene plastic waste into carbonaceous char: priority of plastic waste management amidst 
COVID-19 pandemic. Sci Total Environ 83:149911. https://doi. org/10.1016/j.scitotenv.2021.149911

64. Trninić M, Jovović A, Stojiljković D (2016) A steady state model of agricultural waste pyrolysis: a mini review. Waste Manag Res 34:851-865

65. Tian J, Miller V, Chiu PC, Maresca JA, Guo M, Imhoff PT (2016) Nutrient release and ammonium sorption by poultry litter and wood biochars in stormwater treatment. Sci Total Environ 553:596-606

66. Wu H, Che X, Ding Z, Hu X, Creamer AE, Chen H, Gao B (2016) Release of soluble elements from biochars derived from various biomass feedstocks. Environ Sci Pollut Res 23:1905-1915

67. Yang X, Ng W, Wong BSE, Baeg GH, Wang C-H, Ok YS (2019) Characterization and ecotoxicological investigation of biochar produced via slow pyrolysis: effect of feedstock composition and pyrolysis conditions. J Hazard Mater 365:178-185

68. Engewald W, Pörschmann J (1991) 5 - Solid stationary phases. In: Stationary phases in gas Chromatography. J Chromatogr Libr 48:103-141

69. Wang H, Wang X, Cui Y, Xue Z, Ba Y (2018) Slow pyrolysis polygeneration of bamboo (Phyllostachys pubescens): product yield prediction and biochar formation mechanism. Bioresour Technol 263:444-449

70. Xu D, Cao J, Li Y, Howard A, Yu K (2019) Effect of pyrolysis temperature on characteristics of biochars derived from different feedstocks: a case study on ammonium adsorption capacity. Waste Manag 87:652-660

71. He Q, Raheem A, Ding L, Xu J, Cheng C, Yu G (2021) Combining wet torrefaction and pyrolysis for woody biochar upgradation and structural modification. Energy Convers Manag 243:114383

72. Ferjani AI, Jeguirim M, Jellali S, Limousy L, Courson C, Akrout H, Thevenin N, Ruidavets L, Muller A, Bennici S (2019) The use of exhausted grape marc to produce biofuels and biofertilizers: effect of pyrolysis temperatures on biochars properties. Renew Sustain Energy Rev 107:425-433

73. Yao Y, Gao B, Chen J, Yang L (2013) Engineered biochar reclaiming phosphate from aqueous solutions: mechanisms and potential application as a slow-release fertilizer. Environ Sci Technol 47:8700-8708

74. Vithanage M, Rajapaksha AU, Zhang M, Thiele-Bruhn S, Lee SS, Ok YS (2015) Acid-activated biochar increased sulfamethazine retention in soils. Environ Sci Pollut Res 22:2175-2186

75. Lin Y, Pan Y, Zhang J (2017) CoP nanorods decorated biomass derived N, P co-doped carbon flakes as an efficient hybrid catalyst for electrochemical hydrogen evolution. Electrochim Acta 232:561-569

76. Cui W, Liu Q, Xing Z, Asiri AM, Alamry KA, Sun X (2015) MoP nanosheets supported on biomass-derived carbon flake: one-step facile preparation and application as a novel high-active electrocatalyst toward hydrogen evolution reaction. Appl Catal B Environ 164:144-150

77. Zhou Y, Leng Y, Zhou W, Huang J, Zhao M, Zhan J, Feng C, Tang Z, Chen S, Liu H (2015) Sulfur and nitrogen self-doped carbon nanosheets derived from peanut root nodules as highefficiency non-metal electrocatalyst for hydrogen evolution reaction. Nano Energy 16:357-366

78. An K, Xu X, Liu X (2018) $\mathrm{Mo}_{2} \mathrm{C}$-based electrocatalyst with biomass-derived sulfur and nitrogen co-doped carbon as a matrix for hydrogen evolution and organic pollutant removal. ACS Sustain Chem Eng 6:1446-1455

79. Zhang Y, Zuo L, Zhang L, Huang Y, Lu H, Fan W, Liu T (2016) Cotton wool derived carbon fiber aerogel supported few-layered $\mathrm{MoSe}_{2}$ nanosheets as efficient electrocatalysts for hydrogen evolution. ACS Appl Mater Interfaces 8:7077-7085

80. Kweon DH, Okyay MS, Kim S-J, Jeon J-P, Noh H-J, Park N, Mahmood J, Baek J-B (2020) Ruthenium anchored on carbon nanotube electrocatalyst for hydrogen production with enhanced Faradaic efficiency. Nat Commun 11:1-10

81. Kalyani P, Anitha A (2013) Biomass carbon and its prospects in electrochemical energy systems. Int J Hydrogen Energy 38:4034-4045

82. Zhang L, Jiang J, Holm N, Chen F (2014) Mini-chunk biochar supercapacitors. J Appl Electrochem 44:1145-1151

83. Chen M, Kang X, Wumaier T, Dou J, Gao B, Han Y, Xu G, Liu Z, Zhang L (2013) Preparation of activated carbon from cotton stalk and its application in supercapacitor. J Solid State Electrochem 17:1005-1012

84. Rufford TE, Hulicova-Jurcakova D, Zhu Z, Lu GQ (2008) Nanoporous carbon electrode from waste coffee beans for high performance supercapacitors. Electrochem Commun 10:1594-1597

85. Raymundo-Piñero E, Leroux F, Béguin F (2006) A high-performance carbon for supercapacitors obtained by carbonization of a seaweed biopolymer. Adv Mater 18:1877-1882

86. Jin H, Wang X, Shen Y, Gu Z (2014) A high-performance carbon derived from corn stover via microwave and slow pyrolysis for supercapacitors. J Anal Appl Pyrolysis 110:18-23

87. Ilyas RA, Sapuan SM, Harussani MM, Atikah MSN, Ibrahim R, Asyraf MRM, Radzi AM, Nadlene R, Kian LK, Mali S (2021) Development and characterization of roselle nanocellulose and its potential in reinforced nanocomposites. In: Roselle. Academic Press, p 285-317

88. Ilyas RA, Sapuan SM, Kirubaanand W, Zahfiq ZM, Atikah MSN, Ibrahim R, Radzi AM, Nadlene R, Asyraf MRM, Hazrol MD (2021) Roselle: production, product development, and composites. In: Roselle. Academic Press 1-23

89. Wahid M, Puthusseri D, Phase D, Ogale S (2014) Enhanced capacitance retention in a supercapacitor made of carbon from sugarcane bagasse by hydrothermal pretreatment. Energy Fuels 28:4233-4240

90. Koutcheiko S, Vorontsov V (2013) Activated carbon derived from wood biochar and its application in supercapacitors. $\mathbf{J}$ Biobased Mater Bioenergy 7:733-740

91. Tabac S, Eisenberg D (2021) Pyrolyze this paper: can biomass become a source for precise carbon electrodes? Curr Opin Electrochem 25:100638

92. Borchard N, Wolf A, Laabs V, Aeckersberg R, Scherer HW, Moeller A, Amelung W (2012) Physical activation of biochar and its meaning for soil fertility and nutrient leaching-a greenhouse experiment. Soil Use Manag 28:177-184

93. Zhang H, Voroney RP, Price GW (2017) Effects of temperature and activation on biochar chemical properties and their impact on ammonium, nitrate, and phosphate sorption. J Environ Qual 46:889-896

94. Thines KR, Abdullah EC, Mubarak NM, Ruthiraan M (2017) In-situ polymerization of magnetic biochar-polypyrrole composite: a novel application in supercapacitor. Biomass Bioenergy 98:95-111

95. Yao Y, Gao B, Fang J, Zhang M, Chen H, Zhou Y, Creamer AE, Sun Y, Yang L (2014) Characterization and environmental applications of clay-biochar composites. Chem Eng J 242:136-143

96. Lyu H, Zhang Q, Shen B (2020) Application of biochar and its composites in catalysis. Chemosphere 240:124842

97. Wang L, Chen H, Wu J, Huang L, Brookes PC, Rodrigues JLM, Xu J, Liu X (2021) Effects of magnetic biochar-microbe composite on Cd remediation and microbial responses in paddy soil. J Hazard Mater 414:125494

98. Hu Z, Zhang L, Zhong L, Zhou Y, Xue J, Li Y (2019) Preparation of an antibacterial chitosan-coated biochar-nanosilver composite for drinking water purification. Carbohydr Polym 219:290-297

99. Matykiewicz D (2020) Biochar as an effective filler of carbon fiber reinforced bio-epoxy composites. Processes 8:724 
100. Das O, Bhattacharyya D, Hui D, Lau K-T (2016) Mechanical and flammability characterisations of biochar/polypropylene biocomposites. Compos Part B Eng 106:120-128

101. Nurazzi NM, Asyraf MRM, Fatimah Athiyah S, Shazleen SS, Rafiqah S, Harussani MM, Kamarudin SH, Razman MR, Rahmah M, Zainudin ES (2021) A review on mechanical performance of hybrid natural fiber polymer composites for structural applications. Polymers (Basel) 13:2170

102. Ilyas RA, Sapuan SM, Harussani MM, Hakimi M, Haziq MZM, Atikah MSN, Asyraf MRM, Ishak MR, Razman MR, Nurazzi
NM (2021) Polylactic acid (PLA) biocomposite: processing additive manufacturing and advanced applications. Polymers (Basel) 13:1326

103. Tan X, Liu S, Liu Y, Gu Y, Zeng G, Hu X, Wang X, Liu S, Jiang L (2017) Biochar as potential sustainable precursors for activated carbon production: multiple applications in environmental protection and energy storage. Bioresour Technol 227:359-372 